\title{
Pengaruh Penambahan Tepung Gaplek dan Isolat Bakteri Asam Laktat dari Cairan Rumen Sapi PO Terhadap Kualitas Silase Rumput Gajah (Pennisetum purpureum)
}

\section{The Effect of Cassava Meal and Lactic Acid Bacteria Isolated from Rumen Fluid of PO Cattle on the Quality of Napier Grass Silage}

\author{
I. Jasin dan Sugiyono \\ Fakultas Peternakan Universitas Darul Ulum Islamic Centre Sudirman \\ Kampus Undaris Ungaran Semarang Jawa Tengah \\ e-mail: ismail_jasin@ymail.com
}

(Diterima:23 Desember 2013; Disetujui: 03 Mei 2014)

\begin{abstract}
ABSTRAK
Penelitian tentang pengaruh penambahan tepung gaplek dan isolat bakteri laktat (LAB) diinkubasi dari cairan rumen sapi terhadap silase rumput gajah (Pennisetum purpureum) telah dilaksanakan di Desa Ujung Ujung Pabelan, Kabupaten Semarang. Analisis nilai gizi dilaksanakan di Laboratorium Biokimia Pangan Gizi, Fakultas Ilmu Makanan Ternak, Universitas Gadjah Mada. Penelitian ini menggunakan rancangan acak lengkap terdiri dari 4 perlakuan dan 3 ulangan. Perlakuannya adalah $\mathrm{T} 0=$ kontrol silase, $\mathrm{T} 1=$ silase rumput gajah dengan penambahan tepung gaplek $1 \%$ dan inokulum bakteri asam laktat dari cairan rumen sapi PO $10^{6} \mathrm{cfu} / \mathrm{g}$ hijauan, T2 = silase rumput gajah dengan penambahan tepung gaplek $3 \%$, dan inokulum bakteri asam laktat dari cairan rumen sapi PO $10^{6} \mathrm{cfu} / \mathrm{g}$ hijauan, T3 = silase rumput gajah dengan penambahan tepung gaplek 5\% dan inokulum bakteri asam laktat dari cairan rumen sapi PO $10^{6} \mathrm{cfu} / \mathrm{g}$ hijauan. Parameter yang diamati adalah asam laktat, $\mathrm{pH}$, bahan kering, protein kasar, dan serat kasar. Untuk mengetahui pengaruh perlakuan, analisis data dilanjutkan dengan Uji Duncan. Hasil penelitian ini menunjukkan bahwa penambahan tepung gaplek memberikan pengaruh yang nyata terhadap asam laktat, $\mathrm{pH}, \mathrm{NH} 3$, protein kasar dan serat kasar. Sedang pada bahan kering pengaruhnya tidak nyata. Perlakuan terbaik adalah adalah silase rumput gajah dengan 5\% tepung gaplek.
\end{abstract}

Kata kunci : tepung gaplek, silase rumput gajah, protein kasar, serat kasar

ABSTRACT

The effect of giving cassava meal and inoculums of lactic acid bacteria (LAB) incubated from $P O$ cattles rumen fluid on the quality of napier grass (Pennisetum purpureum) have been done at Ujung ujung village Pabelan, the Semarang district. Analysis of nutritional value was carried out at the Biochemical Nutrition and Food laboratory, Animal Feed Science Faculty, Gadjah Mada University. The research used complete random design consisted of 4 kinds of treatment and 3 replications. There were; $T 0=$ silage control, $T 1=$ silage with cassava meal $1 \%$ and inoculum of lactic bacteria from PO cattles rumen fluid 106 cfu/g forages, T2 = silage with cassava meal $3 \%$ and inoculum of lactic bacteria from PO cattles fluid $106 \mathrm{cfu} / \mathrm{g}$ forage, T3 = silage with cassava meal 5\% and inoculum of lactic bacteria from PO cattles fluid 106 cfu/g forages. The study parameters were lactic acid, $\mathrm{pH}$, dry matter, crude protein, and crude fiber. To verify the effect of treatments, data analysis was continued with the Duncan Test. The results showed that the addition of cassava flour had a significant effect on $\mathrm{LAB}, \mathrm{pH}, \mathrm{NH} 3$ the crude protein and crude fiber. While on dry matter there was not a significant effect. The best treatment was napier grass silage with $5 \%$ of cassava meal.

Keywords : cassava meal, napier grass silage, crude protein, crude fiber 


\section{PENDAHULUAN}

Kekurangan hijauan segar sebagai pakan ternak sudah lama dirasakan oleh para peternak. Seringkali peternak menanggulanginya dengan cara memberikan pakan seadanya yang diperoleh dengan mudah dari lingkungan sekitarnya. Pemberian pakan seadanya sangat mempengaruhi produktivitas ternak, terlihat terlambatnya pertumbuhan dan rendahnya penambahan bobot badan bahkan mengalami sakit. Pengawetan hijauan segar yang disebut silase diharapkan dapat mengatasi permasalahan kekurangan nijauan segar terutama pada musim kemarau yang selanjutnya dapat memperbaiki produktivitas ternak. Produktivitas ternak merupakan fungsi dari ketersediaan pakan dan kualitasnya (Leng, 1991).

Pembuatan silase merupakan salah satu cara yang sangat bermanfaat untuk tetap menggunakan bahan tanaman dengan kualitas nutrisi yang tinggi sebagai pakan ternak disepanjang waktu, tidak hanya untuk waktu musim kemarau (Perry, et al., 2003). Ketersediaan pakan dipengaruhi oleh beberapa faktor diantaranya suhu harian, iklim, dan ketersediaan air tanah. Faktor tersebut sangat mempengaruhi ketersediaan hijauan pakan ternak yang diharapkan kontinyu sepanjang tahun (Ridwan dan Widyastuti, 2003).

Teknologi pembuatan silase sudah lama dikenal dan berkembang dengan pesat di negara yang mengalami musim dingin. Prinsip pembuatan silase adalah fermentasi hijauan yang dilakukan oleh bakteri asam laktat secara anaerob. Bakteri asam laktat akan menggunakan karbohidrat yang terlarut dalam air dan menghasilkan asam laktat. Asam ini akan berperan dalam penurunan $\mathrm{pH}$ silase (Ennahar, et al., 2003). Selama proses fermentasi asam laktat yang dihasilkan akan berperan sebagai zat pengawet sehingga dapat menghindarkan pertumbuhan mikroorganisme pembusuk.

Bakteri asam laktat dapat diharapkan secara otomatis tumbuh dan berkembang pada saat dilakukan fermentasi secara alami, tetapi untuk menghindari kegagalan fermentasi dianjutkan untuk melakukan penambahan inokulum bakteri asam laktat yang homofer- mentatif, agar terjamin berlangsungnya fermentasi asam laktat. Inokulum bakteri asam laktat merupakan additive yang paling populer dibandingkan asam, enzim, dan sumber karbohidrat lainnya (Bolsen et al., 1995). Bahkan inokulum silase dapat juga sebagai probiotik karena sifatnya masih dapat hidup sampai bagian lambung utama dari ruminansia yaitu rumen (Weimberg et al., 2004)

Keberhasilan pembuatan sialse dipengaruhi oleh kadar air hijauan yang digunakan, zat aditif yang digunakan untuk meningkatkan kadar protein dan kadar gula terlarut, jumlah bakteri penghasil laktat dan kadar oksigen. Kurangnya kadar gula terlarut dalam silase menyebabkan bakteri asam laktat kekurangan asupan energi untuk melakukan aktivitasnya, sehingga bakteri asam laktat akan menggunakan zat-zat lain yang terkandung dalam hijauan yang memungkinkan digunakan sebagai sumber energi yang menyebabkan berkurangnya nilai nutrisi hijauan tersebut. Untuk menjamin ketersediaan gula terlarut yang menjamin keberhasilan proses ensilase perlu dilakukan penambahan bahan aditif. Aditif dari sumber karbohidrat yang dapat dimanfaatkan antara lain adalah gaplek, bakteri asam laktat.

Gaplek merupakan salah satu bahan ditambahkan dalam bahan pakan yang akan disilase dapat mempercepat penurunan $\mathrm{pH}$ karena gaplek menyediakan karbohidrat yang tinggi yang digunakan oleh bakteri asam laktat sebagai energi dalam pembentukan asam laktat (Susetyo et al., 1969). Ciri-ciri fermentasi berjalan kurang baik yakni tingginya kadar asam butirat, $\mathrm{pH}$, kadar ammonia dan amin, sedangkan ciri-ciri proses fementasi yang sempurna yakni $\mathrm{pH}$ turun dengan cepat, tidak adanya bakteri Clostradia, kadar ammonia rendah (Driehuis dan Oude Elferink, 2000).

Penelitian ini bertujuan untuk mengevaluasi pengaruh penambahan tepung gaplek dan penambahan isolat bakteri asam laktat dari cairan rumen sapi Po terhadap kualitas silase rumput gajah (Pennisetum purpureum). 


\section{METODE}

Penelitian ini telah dilakukan di Desa Ujung-ujung Kecamatan Pabelan Kabupaten Semarang Provinsi Jawa Tengah selama 2 bulan. Kandungan zat makanan dilakukan di Laboratorium Biokimia Nutrisi Makanan Ternak Fakultas Peternakan Universitas Gadjah Mada Yogyakarta.

Bahan yang digunakan dalam penelitian ini adalah rumput gajah yang ditanam di kebun kelompok tani ternak Sumber Urip Desa Ujung-ujung Kecamatan Pabelan Kabupaten Semarang Provinsi Jawa Tengah, tepung gaplek yang digunakan berasal dari Desa Pondong Kabupaten Gunung Kidul Provinsi Daerah Istimewa Yogyakarta, inokulum bakteri asam lakat diperoleh dari hasil isolasi dan identifikasi bakteri asam laktat dari cairan rumen sapi PO (Jasin et al, 2012).

Penelitian ini menggunakan alat-alat yang terdiri dari : 2 buah sabit sebagai alat pencacah rumput, 1 buah timbangan kapasitas $5 \mathrm{~kg}$, polybag berukuran $60 \times 120 \mathrm{~cm}$, plastik berukuran $28 \times 50 \mathrm{~cm}$, pompa vakum Pollicon merek Phillps

\section{Rancangan Percobaan}

Penelitian ini menggunakan Rancangan Acak Lengkap (RAL) yang terdiri dari 4 macam perlakuan dan diulang 3 kali. Perlakuan yang diberikan yaitu:

T0 : Silase rumput gajah dengan penambahan tepung gaplek $0 \%$, dan inokulum bakteri asam laktat dari cairan rumen sapi PO (Kontrol)

T1 : Silase rumput gajah dengan penambahan tepung gaplek $1 \%$, dan inokulum bakteri asam laktat dari cairan rumen sapi PO $10^{6}$ cfu/g hijauan

T2 : Silase rumput gajah dengan penambahan tepung gaplek 3\%, dan inokulum bakteri asam laktat dari cairan rumen sapi PO $10^{6}$ cfu/g hijauan

T3 : Silase rumput gajah dengan penambahan tepung gaplek $5 \%$, dan inokulum bakteri asam laktat dari cairan rumen sapi PO $10^{6}$ cfu/g hijauan

\section{Pengolahan data}

Data yang diperoleh dianalisis dengan menggunakan statistik Analisa Varian (ANOVA), bila terdapat perbedaan antar perlakuan dilanjutkan dengan uji jarak berganda Duncan's (Duncan's Multiple Range Test) dengan derajat kepercayaan $95 \%$ (Kusriningrum, 2010)

\section{Pembuatan Silase}

Silase dibuat dari rumput gajah yang dilayukan selama satu hari kemudian dipotong-potong menjadi ukuran 3-5 cm. Setelah itu dicampur merata dengan tepung gaplek masing-masing menurut perlakuan $(0 \%, 1 \%$, $3 \%, 5 \%)$ dan ditambahkan inokulum bakteri asam laktat masing-masing perlakuan sebanyak $10^{6} \mathrm{Cfu} / \mathrm{g}$ hijauan (Weimberg et al., 2004). Campuran kemudian dimasukkan ke dalam plastik. Udara dikeluarkan dari kantong plastik tersebut menggunakan pompa vakum Kantong ditutup dan kemudian dilapisi dengan plastik lainnya hingga 3 lapis. Setelah itu, kantong dimasukkan ke dalam polybag ukuran $60 \times 120 \mathrm{~cm}$ untuk menghindari dari cahaya dan diinkubasi pada suhu ruangan selama 30 hari.

Parameter yang diamati dalam penelitian ini adalah kandungan asam laktat diukur dengan menggunakan metode Cappucino dan Natalie (2001), derajat keasaman $(\mathrm{pH})$ diukur dengan menggunakan metode Dairy One (2007), kandungan NH3 diukur dengan menggunakan metode Mikrodifusi Conway (AOAC, 1990) serta kandungan bahan kering, dan kandungan bahan organik.

\section{HASIL DAN PEMBAHASAN}

Pengaruh perlakuan terhadap parameter yang diamati : kandungan asam laktat, $\mathrm{NH}_{3}$, dan derajat keasaman $(\mathrm{pH})$ tertera pada Tabel 1.

\section{Kandungan Asam laktat}

Hasil analisis ragam menunjukkan penambahan tepung gaplek memberikan pengaruh nyata $(\mathrm{P}<0,05)$ terhadap kandungan asam laktat silase rumput gajah. Semakin tinggi level penambahan level tepung gaplek maka semakin tinggi pula rata-rata kandungan 
Tabel 1. Rata-rata kandungan asam laktat, kandungan $\mathrm{NH}_{3}$, dan derajat keasaman $(\mathrm{pH})$ setiap perlakuan selama penelitian.

\begin{tabular}{|c|c|c|c|c|}
\hline \multirow{2}{*}{ Perlakuan } & \multicolumn{4}{|c|}{ Perlakuan } \\
\hline & T0 & $\mathrm{T} 1$ & $\mathrm{~T} 2$ & T3 \\
\hline Kandungan asam laktat ( \%) & $4,82^{\mathrm{a}}$ & $9,48^{b}$ & $9,75^{b}$ & $10,05^{\mathrm{b}}$ \\
\hline Kandungan $\mathrm{NH}_{3}(\mathrm{mM} / \mathrm{g} \mathrm{BK})$ & $7,15^{\mathrm{a}}$ & $4,97^{b}$ & $4,85^{\mathrm{b}}$ & $4,01^{\mathrm{b}}$ \\
\hline Derajat keasaman $(\mathrm{pH})$ & $4,95^{\mathrm{a}}$ & $3,81^{b}$ & $3,88^{\mathrm{b}}$ & $4,60^{\mathrm{b}}$ \\
\hline
\end{tabular}

asam laktat silase rumput gajah. Hal ini karena penambahan tepung gaplek sebagai sumber karbohidrat terlarut sehingga merangsang terjadinya fermentasi berjalan baik dan nutrisi yang cukup bagi perkembangan bakteri asam laktat untuk menghasilkan asam laktat.

Kandungan asam laktat silase rumput gajah yang dihasilkan dengan penambahan tepung gaplek nyata lebih tinggi dibandingkan kontrol dan pemberian tepung gaplek sebanyak 5\% mengahasilkan kandungan asam laktat tertinggi yaitu mencapai $10,05 \%$ akan tetapi hasil ini tidak menunjukkan perbedaan yang nyata dengan penambahan tepung gaplek $1 \%$ dan $3 \%$.

\section{Kandungan $\mathrm{NH}_{3}$}

Hasil analisis ragam menunjukkan bahwa penambahan level tepung gaplek memberikan pengaruh yang nyata $(\mathrm{P}<0,05)$ terhadap kandungan $\mathrm{NH}_{3}$ dibandingkan dengan kontrol. Kandungan $\mathrm{NH}_{3}$ pada perlakuan T0, tanpa penambahan tepung gaplek nyata lebih tinggi dibandingkan dengan perlakuan dengan penambahan tepung gaplek T1, T2, dan T3. Hal ini karena kandungan asam laktat yang dihasilkan pada perlakuan T0 cukup rendah dan $\mathrm{pH}$ cukup tinggi sehingga suasana asam tidak tercapai dan menyebabkan terjadinya proses deaminasi protein oleh bakteri yang bersifat proteolitik sehingga akan menguraikan asam organik menjadi ammonia.

Hal ini sejalan dengan pendapat (Kaiser, 1984; Woolford, 1984; McDonald et al., 2002) yang menyatakan bahwa pemecahan asam amino dan pembentukan amonia sebagian besar dilakukan oleh bakteri Clostridium. Pada fermentasi ini asam laktat dipecah menjadi asam butirat, selain itu juga terjadi deaminasi dan dekarboksilasi asam amino membentuk ammonia $\left(\mathrm{NH}_{3}\right)$. Tetapi antara perlakuan tidak terdapat perbedaan kandungan NH3. Rataan kandungan $\mathrm{NH}_{3}$ silase rumput gajah berkisar antara $4,01 \mathrm{mM} / \mathrm{g}$ BK sampai $4,97 \mathrm{mNm} / \mathrm{g}$ BK. Semakin tinggi level penambahan tepung gaplek maka semakin rendah pula kandungan $\mathrm{NH}_{3}$. Hal ini dikarenakan asam laktat yang dihasilkan pada penambahan level tepung gaplek semakin meningkat sedangkan $\mathrm{pH}$ yang dihasilkan semakin rendah, artinya kandungan karbohidrat terlarut yang terkandung dalam tepung gaplek mampu menstimulir pertumbuhan bakteri asam laktat untuk membentuk asam laktat untuk mencapai kondisi asam. Hal ini sejalan dengan pendapat Health et al., (1973), menyatakan bahwa lebih banyak sumber karbohidrat terarut yang tersedia akan mempermudah proses fermentasi, menambah keasaman dan cenderung mengurangi kerusakan protein.

Silase yang memiliki kualitas baik memiliki kandungan $\mathrm{NH}_{3}$ kurang dari $11 \%$ dari total nitrogen (Bolsen, 1978 dalam Kurnani, 1995). Berdasarkan nilai kandungan $\mathrm{NH}_{3}$ yang dihasilkan pada tiap perlakuan diperoleh nilai kandungan $\mathrm{NH}_{3}<11 \%$ dengan demikian jika dilihat dari nilai berada pada kisaran $\mathrm{NH}_{3}$ yang berkriteria baik.

\section{Derajat Keasaman (pH)}

Hasil analisis ragam menunjukkan bahwa penambahan tepung gaplek memberikan pengaruh yang nyata $(\mathrm{P}<0,05)$ terhadap $\mathrm{pH}$ silase rumput gajah. $\mathrm{pH}$ silase yang tidak mendapat tambahan tepung gaplek (perlakuan T0) nyata lebih tinggi dibandingkan dengan 
Tabel 2. Rata-rata kandungan bahan kering, protein kasar, $\mathrm{NH}_{3}$ pada silase rumput gajah dengan penambahan tepung gaplek dan inokulum bakteri asam laktat dari cairan rumen sapi $\mathrm{PO}$

\begin{tabular}{lcccc}
\hline \multirow{2}{*}{ Parameter } & \multicolumn{4}{c}{ Perlakuan } \\
\cline { 2 - 5 } & $\mathrm{T} 0$ & $\mathrm{~T} 1$ & $\mathrm{~T} 2$ & $\mathrm{~T} 3$ \\
\hline Bahan kering (\%) & $36,58^{\mathrm{a}}$ & $35,35^{\mathrm{a}}$ & $34,35^{\mathrm{a}}$ & $33,15^{\mathrm{a}}$ \\
Protein kasar (\%) & $10,15^{\mathrm{a}}$ & $12,20^{\mathrm{b}}$ & $13.40^{\mathrm{b}}$ & $15,96^{\mathrm{c}}$ \\
Serat kasar (\%) & $24,98^{\mathrm{a}}$ & $20,65^{\mathrm{b}}$ & $16,85^{\mathrm{c}}$ & $15,73^{\mathrm{c}}$ \\
\hline
\end{tabular}

Keterangan : a,b,c , angka dalam baris yang sama menunjukkan superscript yang berbeda sangat nyata $(\mathrm{P}<0,01)$

yang mendapat tambahan tepung gaplek sedangkan antara $\mathrm{T} 1, \mathrm{~T} 2$, dan $\mathrm{T} 3$ tidak memperlihatkan perbedaan yang nyata. Semakin tinggi penambahan tepung gaplek maka semakin rendah rata-rata $\mathrm{pH}$ silase rumput gajah. Hal ini menunjukkan bahwa penambahan tepung gaplek pada proses ensilase rumput gajah mampu memberikan kondisi yang layak bagi perkembangan bakteri pembentuk asam laktat sehingga $\mathrm{pH}$ menjadi cepat turun. Hal ini sejalan dengan pendapat Perry et al. (2003), menyatakan bahwa penambahan bahan kaya akan karbohidrat dapat mempercepat penurunan $\mathrm{pH}$ silase karena karbohidrat merupakan energi bagi bakteri pembentuk asam laktat.

Rata-rata derajat keasaman $(\mathrm{pH})$ silase rumput gajah berkisar antara 3,65 sampai 3,88 menghasilkan silase yang baik. Hal ini sejalan dengan pendapat Haustein et al., (2003) menyatakan bahwa silase yang ber-pH dibawa 4,2 maka silase tersebut berkualitas baik sedangkan silase yang ber-pH antara 4,5- 5,2 maka silase tersebut berkualitas cukup baik. Selanjutnya Skerman dan Riveros (1990). Menyatakan bahwa silase yang baik mempunyai nilai derajat keasaman $<4,2$. Rendahnya nilai derajat keasaman silase rumput gajah yang dihasilkan menunjukkan bahwa asam laktat dan asam organik lain yang dihasilkan cukup banyak, sehingga mampu menurunkan derajat keasaman silase.

\section{Bahan Kering Silase}

Pengaruh perlakuan terhadap bahan kering silase rumput gajah dengan penambahan tepung gaplek disajikan pada Tabel 2 . Hasil analisis ragam menunjukkan bahwa penambahan tepung gaplek tidak memberikan pengaruh nyata terhadap kandungan bahan kering pada silase rumput gajah, namun terlihat kecenderungan menurun. Rata-rata bahan kering silase rumput gajah yang dihasilkan berkisar antara 32,15\% - 35,35\%. Penambahan tepung gaplek pada pembuatan silase rumput gajah dapat meningkatkan kemampuan bakteri asam laktat memanfaatkan karbohidrat terlarut sehingga banyak kadar air yang dilepaskan dari rumput atau dengan adanya perbedaan antara daya adhesi dan kohesi. Sehingga dengan semakin banyak sumber karbohidrat yang ditambahkan akan menurunkan kadar bahan kering secara perlahan-lahan.

Kandungan bahan kering silase rumput gajah cenderung mengalami penurunan dengan adanya penambahan level tepung gaplek, hal ini berkaitan dengan kandungan air. Menurut Hall (1970) perkembangan mikroorganisme dipengaruhi oleh suhu dan air. Kandungan air yang tinggi pada bahan merupakan media yang baik untuk partumbuhan berbagai mikroba, dengan banyaknya populasi mikroba maka akan lebih banyak memecah bagian makanan sebagai sumber energi seperti karbohidrat, protein, dan lemak. Keadaan ini akan menurunkan kadar bahan kering dari bahan pakan.

Suhardjo et al. (1986) menyatakan bahwa selama proses penyimpanan, penurunan bahan kering dapat terjadi akibat aktifitas enzim, mikroorganisme, proses oksidasi dengan membentuk uap air sehingga kandungan air meningkat.

\section{Protein Kasar Sllase}

Pengaruh perlakuan terhadap protein kasar silase rumput gajah dengan penambahan tepung gaplek disajikan pada Tabel 2. Hasil analisis ragam menunjukkan bahwa penamba- 
han tepung gaplek memberikan pengaruh sangat nyata $(\mathrm{P}<0,01)$ terhadap kandungan protein kasar pada silase rumput gajah, semakin tinggi level penambahan tepung gaplek maka semakin tinggi pula rata-rata persentase protein kasar pada silase rumput gajah.

Selama proses ensilase bakteri asam laktat yang ada pada hijauan akan memanfaatkan hijauan sebagai sumber energi dan menghasilkan asam-asam organik terutama asam laktat, sehingga protein mengalami perombakan.

\section{Serat Kasar Silase}

Pengaruh perlakuan terhadap serat kasar silase rumput gajah dengan penambahan tepung gaplek disajikan pada Tabel 2. Hasil analisis ragam menunjukkan bahwa penambahan tepung gaplek memberikan pengaruh sangat nyata $(\mathrm{P}<0,01)$ terhadap kandungan serat kasar pada silase rumput gajah.

Penambahan tepung gaplek cenderung menurunkan kandungan serat kasar silase rumput gajah, hal ini dikarenakan tepung gaplek mempunyai kandungan serat kasar yang lebih rendah daripada rumput gajah, sehingga silase yang ditambahkan tepung gaplek lebih rendah serat kasarnya daripada silase tampa penambahan tepung gaplek.

Woolford (1984) menjelaskan bahwa persentase serat kasar rendah karena adanya perombakan oleh bakteri, dimana selulose dan hemiselulose dapat dirombak menjadi bagian yang lebih sederhana. Selanjutnya Anggorodi (1984) menyatakan bahwa dengan terombaknya selulose yang merupakan salah satu komponen serat kasar maka kandungan serat kasar seperti selulose, lignin dan hemiselulose menjadi rendah. Serat kasar di dalam silase merupakan sumber gula cadangan yang akan digunakan bila sumber karbohidrat yang mudah digunakan telah habis.

Hemiselulose dapat berfungsi sebagai sumber gula cadangan dalam silase dan sekitar $11-55 \%$ dari hemiselulose ini dapat dirombak menjadi yang lebih sederhana (Mc. Donald, 1984). Serat mengandung selulose, lignin, dan polisakarida lainnya. Senyawa tersebut mempunyai suatu ikatan kompleks yang sangat sukar dirombak oleh mikroorganisme, sehing- ga mikroorganisme tidak dapat menggunakan serat kasar pada awal terjadinya proses fermentasi.

\section{KESIMPULAN}

Dari hasil penelitian ini dapat disimpulkan sebagai berikut:

1. Penambahan tepung gaplek dan inokulum bakteri asam laktat dari cairan rumen sapi PO pada silase rumput gajah menunjukkan pengaruh yang nyata $(\mathrm{P}<0,05)$ terhadap kandungan asam laktat, $\mathrm{pH}, \mathrm{NH}_{3}$, sangat nyata $(\mathrm{P}<0,01)$ pada kandungan protein kasar, kandungan serat kasar. Sedangkan pada kandungan bahan kering menunjukkan pengaruh yang berbeda tidak nyata.

2. Penambahan tepung gaplek dengan level yang berbeda menunjukkan perubahan pada kualitas silase rumput gajah dimana meningkatnya kandungan protein kasar dan menurunkan $\mathrm{pH}$ serta kandungan bahan kering serta serat kasar.

3. Kualitas silase rumput gajah yang baik terdapat pada perlakuan T3 yaitu dengan penambahn $5 \%$ tepung gaplek.

\section{UCAPAN TERIMAKASIH}

Penulis mengucapkan terima kasih kepada Dinas Pendidikan Provinsi Jawa Tengah yang telah mendanai penelitian ini melalui proyek Kegiatan Program Penerapan dan Pengembangan Desa Vokasi Tahun 2012.

\section{DAFTAR PUSTAKA}

Anggorodi. 1984. Ilmu Makanan Ternak Umum. Gramedia, Jakarta

AOAC. 1990. Official Methods of Analysis. Association of Official Analytical Chemists, $15^{\text {th }}$ ed. Washington, DC., USA.

Bolsen, K.K., M. Ashbell, G., and J.M. Wilkinnson. 1995. Silage Aditifs in Biotechnology in Animal Feeding. R.J. Wallace \& A. Chesson (Eds). VCH, Weinheim. 
Cappuccino, J.G., S.Natalie. 2001. Microbiology, a Laboratory Manual. $6^{\text {th }}$ edition. New York. State University of New York.

Dairy One. 2007. Dairy one forage Lab. Analytical Procedures (http://www. Dairyone.com/Forage/Procedures/defaul t.html). [Agustus 2013]

Driehuis, F. dan S.J. Oude Elferink. 2000. The impact of the quality of the silage on animal health and food safety : a review. Veterinary Q. 22:212-216

Ennahar. S., Y. Cai., and Y. Fujita. 2003. Phylogenetic diversity of lactic acid bacteria associated with paddy rice silage as determined by $16 \mathrm{~S}$ ribosomal DNA analysis. Applied and Enviromental Microbiology 69 (1): 444-451.

Filya, I. 2003. The effect of Lactobacllus buchneri and Lactobacillus plantarum on the fermentation, aerobic stability, and ruminal degradability of low dry matter corn and sorgum silages. J.Dairy Sci. 86:3575-3581.

Hall, DW., 1970. Handling And Storage of Food in Tropical And Subtropical Areas, FAO, Rome.

Haustein, Stefan and Morik, Katharina and Pleumann, Jörg. 2003. The InfoLayer A Simple Knowledge Management System Put to Use in Academica. In IKnow-03, Springer.

Health, M.E., D.S. Metcalf and R.F. Barnes. 1973. Forage. The Science Of Grassland Agriculture. $3^{\text {th }} \mathrm{Ed}$ The Iowa State University Press.USA. p.5-23, 556-566.

Jasin, I., Sugiyono dan Sriwahyuni. 2012. Isolation And Identification of Acid Lactic Bacteria From PO Cattles Gastric Fluid as Apotential Candidate of Biopreservative Preeseding International seminar $4^{\text {th }}-6^{\text {th }}$ September 2013. Faculty of Veterinary Medical Airlangga University Surabaya.
Kaiser, A.G. 1984. The influence of silage fermentation on animal production. Prpc. of Nat. Worshop. New South Wales. Australia.

Kurnani, A.B.1995. Pengaruh penambahan berbagai kombinasi dedak, tetes dan urea pada panjang cacahan rumput raja (Penisetum purpupoides) yang berbeda terhadap kualitas silase yang diukur secara kimia dan biologis pada domba. Disertasi. Universitas Padjadjaran. Bandung Indonesia.

Kusriningrum,R.S. 2010. Perancangan Percobaan. Cet-2. Ailangga University Press. Surabaya.

Leng, R.A., 1991. Application of biotechnology to nutrition of animals in developing countries. FAO Animal Production and Health Paper no 90, Rome, Italy.

McDonald, P., R.A. Edwards, J.F.D. Greenhalgh, and C.A. Morgan. 2002. Animal Nutrition, $6^{\text {th }}$ Ed. Prentice Hall, London

Perry, A.E. Cullison, R.S. Lowrey, 2003. Feeds and Feeding, $3^{\text {rd }}$ Ed Practice Hall of India. New Delhi, India.

Ridwa, R. dan Y. Widyastuti. 2003. Manual pengawetan HMT (Hijauan Makanan Ternak) dengan inokulum bakteri asam laktat. Puslit Bioteknologi-LIPI. Cibinong, Bogor.

Suhardjo, L.L. Harper, L.D. Brady and D. Judya. 1986. Pangan, Gizi dan Pertanian. UI-Press, Jakarta.

Susetyo, Kismono dan B. Soewardi, 1969. Hijauan makanan ternak. Direktorat Peternakan Rakyat Direktorat Jenderal Peternakan Departemen Pertanian. Jakarta

Skernan, P.J., F. Riveros. 1990. Tropical grasses. FAO plant production series (23). Food and Agriculture of the United Nation,Roma.

Weinberg, Z.G., R.E. Muck, P.J. Weimer, Y. Chen, and M. Gamburg. 2004. Lactic 
Vol. 16 (2)

acid bacteria used in inaculants for silage as probiotics for ruminants. Applied Biochemistry Biotechnology. 118:1-10.
Woolford, M.K., 1984. The Silage Fermentation. Marcel Dekker Inc. New York. 